\title{
Photochemical efficiency of photosystem II in rapidly dehydrating leaves of 11 temperate and tropical tree species differing in their tolerance to drought
}

\author{
E Dreyer 1, D Epron 1, OE Yog Matig 2 \\ ' INRA-Nancy, Laboratoire de Bioclimatologie et d'Écophysiologie Forestières, \\ Station de Sylviculture et Production, Champenoux, F-54280 Seichamps, France; \\ 2 IRA-Garoua, Centre de Recherches Agronomiques, Garoua, Cameroon
}

(Received 10 July 1992; accepted 7 September 1992)

\begin{abstract}
Summary - Responses of PS II photochemical efficiency to rapid and severe leaf dehydration were tested on 11 different tree species differing in their ability to withstand periods of drought. Seedlings of Quercus robur, $Q$ petraea, $Q$ pubescens, $Q$ rubra, $Q$ cerris and $Q$ ilex, and Dalbergia sissoo, Eucalyptus camaldulensis, Acacia holosericea, Azadirachta indica and Populus candicans were grown in a greenhouse at Nancy. Fifty to 60 leaf disks were punched from a few well-watered and dark-adapted seedlings and left to dehydrate in complete darkness for up to $6 \mathrm{~h}$. Chlorophyll fluorescence induction kinetics were recorded with a PAM fluorometer (modulated red light below $1 \mu \mathrm{mol} . \mathrm{m}^{-2} \mathrm{~s}^{-1}$, actinic light $220 \mu \mathrm{mol} \cdot \mathrm{m}^{-2} \cdot \mathrm{s}^{-1}$, saturating white flashes, $\left.4000 \mu \mathrm{mol} \cdot \mathrm{m}^{-2} \cdot \mathrm{s}^{-1}\right)$. All species displayed a remarkable stability for initial and maximal fluorescence $F_{0}$ and $F_{\mathrm{m}}$, for PS II photochemical efficiency of dark-adapted disks, and after $10 \mathrm{~min}$ at $220 \mu \mathrm{mol} \mathrm{m}^{-2} \mathrm{~s}^{-1}$, up to relative water losses largely above the turgor loss point. Decreases in the latter were the first observed signs of dysfunction at leaf relative water losses of $\approx 0.23-0.40$ depending on the species. They were generally accompanied by significant decreases in the photochemical efficiency of open reaction centers, which revealed increased PS II thermal deexcitation. No correlation between evolution of either of these parameters and known tolerance to drought could be detected among tested species. It is concluded that sensitivity of the photosynthetic apparatus to leaf dehydration in the absence of irradiance plays a very minor role in the adaptation of species to drought. Photosynthesis decline in response to water stress under natural conditions is probably the consequence of stomatal closure and possibly of high levels of irradiance and temperature.
\end{abstract}

photosynthesis / chlorophyll fluorescence / PS II photochemical efficiency / water stress / dehydration / oak species / tropical tree species

\footnotetext{
Abbreviations: $D$ : relative leaf water loss; $D=0$ at full turgor; $D_{11}$ : relative leaf water loss at turgor loss; $\pi_{\mathrm{p}}$ : osmotic potential at full turgor; $\psi_{\mathrm{w}}$ and $\psi_{\mathrm{w} t}$ : leaf water potential, actual value and at turgor loss; PS II: photosystem II; $F_{\mathrm{m}}$ : maximal fluorescence; $F_{0}$ : initial fluorescence; $F_{\mathrm{v}}=F_{\mathrm{m}}-F_{0} ; F_{\mathrm{v}} / F_{\mathrm{m}}$ : PS II photochemical efficiency of dark-adapted leaves; $F_{m^{\prime}}, F$ and $F_{0}$ : maximal fluorescence, steady state and basic fluorescence after $10 \mathrm{~min}$ induction at $220 \mu \mathrm{mol} \mathrm{m} \mathrm{m}^{-2} \mathrm{~s}^{-1}$ photon flux density; $F_{\mathrm{v}^{\prime}}=F_{\mathrm{m}^{\prime}}$ - $F_{0} ; \Delta F=F_{\mathrm{m}}-F_{;} \Delta F / F_{\mathrm{m}}$ : PSII photochemical efficiency measured after a 10-min induction period at $220 \mu \mathrm{mol} \mathrm{m}-2 \mathrm{~s}^{-1} ; F_{\mathrm{v}} / F_{\mathrm{m}}$ : photochemical efficiency open photosynthetic reaction centers under the same conditions; qp: photochemical quenching under the same irradiance; DW: dry weight; FW. fresh weight; $F W_{i}$ initial fresh weight; LSW: leaf specific weight.
} 
Résumé - Comparaison des effets d'une déshydratation rapide sur l'efficience photochimique du photosystème II de 11 espèces ligneuses présentant des degrés variables de résistance à la sécheresse. Les diminutions d'efficience photochimique du photosynthèse /l en réponse à une déshydratation rapide et sévère de feuilles, ont été comparées sur 11 espèces d'arbres connues pour présenter des degrés variables de tolérance à des conditions de sécheresse. Des semis de différents chênes (Quercus robur, Q petraea, $Q$ pubescens, $Q$ rubra, $Q$ cerris et $Q$ ilex), d'espèces tropicales (Dalbergia sissoo, Eucalyptus camaldulensis, Acacia holosericea, Azadirachta indica) et de peuplier (Populus candicans) ont été élevés en serre à Nancy. Cinquante à soixante disques foliaires ont été prélevés sur des plants bien alimentés en eau et préalablement maintenus à l'obscurité. IIs ont transpiré librement à l'obscurité pendant des temps variables pouvant aller jusqu'à $6 \mathrm{~h}$. Leur degré de déshydratation a été estimé par leur teneur en eau relative au moment des mesures. Les cinétiques d'induction de fluorescence ont été enregistrées sur chacun de ces disques en utilisant un fluoromètre modulé PAM (densités de flux de photons : lumière modulée rouge : $<1 \mu \mathrm{mol} \cdot \mathrm{m}^{-2} . \mathrm{s}^{-1}$; lu-

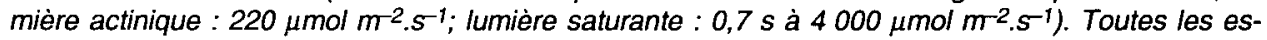
pèces ont présenté une remarquable stabilité de la fluorescence de base et de la fluorescence maximale, ainsi que de l'efficience photochimique du photosystème II tant maximale qu'après une induction à $220 \mu \mathrm{mol} \mathrm{m} \mathrm{m}^{2} \cdot \mathrm{s}^{-1}$, et ce jusqu'à des teneurs en eau largement en deçà de celles correspondant à la perte de turgescence. Les premiers signes de dysfonctionnement observés ont consisté en une baisse de l'efficience photochimique à $220 \mu \mathrm{mol} \mathrm{m}^{-2} . \mathrm{s}^{-1}$, qui a débuté à des déficits de teneur en eau relative de l'ordre de 0,23 à 0,40 suivant l'espèce. Cette baisse était généralement accompagnée d'une diminution de l'efficience photochimique des centres ouverts révélant ainsi une augmentation significative de la déexcitation thermique du PS II. Mais aucune corrélation n'a pu être étabii: entre la réponse de ces paramètres à la déshydratation et la tolérance globale des espèces à la sécheresse. La sensibilité de l'appareil photosynthétique foliaire à la déshydratation elle-même ne joue sans doute qu'un rôle mineur dans l'adaptation des espèces aux déficits d'alimentation hydrique. Les diminutions de photosynthèse observees en réponse à l'épuisement progressif des réserves hydriques du sol en conditions naturelles sont vraisemblablement dues à une fermeture des stomates, accompagnée parfois par une action des fortes irradiances et des températures élevées.

photosynthèse / fluorescence chlorophyllienne / efficience photochimique du PSII / stress hydrique / déshydratation / chêne / espèce tropicale

\section{INTRODUCTION}

Water availability plays a major role in the distribution of tree species all over the world. But the physiological basis of the observed differences in tolerance to water shortage still has to be clarified. In particular, survival and growth of trees under conditions of low water availability imply optimization of water use through stomatal regulation, high photosynthetic efficiency in leaves during the short periods of water availability and long-term survival of these leaves during periods of stress.

Does tolerance of the photosynthetic apparatus to leaf dehydration play any role in these stress adaptations? The photo- synthetic apparatus appears to be rather tolerant to dehydration (Kaiser, 1987) and many authors claim that the main effect of water strees is to induce stomatal closure and to limit photosynthesis via reduced supply of $\mathrm{CO}_{2}$ to chloroplasts (Cornic et al, 1989; Chaves, 1991). The use of chlorophyll a fluorescence is one of the different techniques suitable for studying photosynthesis tolerance to environmental constraints. From such measurements it has been shown that PS II displays good stability up to very low levels of water content in leaves. Rapidly dehydrated leaves show a constant basic fluorescence $F_{0}$ and a high maximal photochemical efficiency $F_{V} / F_{m}$ (Ögren and Öquist, 1985; Cornic et al, 1987; Epron and Dreyer, 1992). Epron and 
Dreyer (1992) suggested that the first signs of dehydration-induced impairment were increases in a fast relaxing nonphotochemical quenching of fluorescence, which appeared at a relative leaf water loss $>0.35$ in $Q$ petraea and which was interpreted as an increase in PS II thermal deexcitation related to reduced electron consumption and decreased activity of the carbon reduction and photorespiratory cycles. The question nevertheless remains open whether these features could be generalized to a broader range of species. In particular, it is not clear if differences in leaf structural characteristics (such as chlorophyll content per unit leaf area or leaf specific weight), leaf water relations (osmotic potential at full turgor or water content at turgor loss), and more generally in drought tolerance could be related to some modifications in the above-described reactions to dehydration. We therefore compared the changes induced by rapid dehydration in the dark, on PSII photochemical efficiency of dark-adapted leaves and after a 10-min induction period at $220 \mu \mathrm{mol} \mathrm{m}-2 \mathrm{~s}^{-1}$ on leaf disks from seedlings of a broad range of species, including mesophytic oaks, xerophytic oaks and intertropical species used for reforestation under semi-arid conditions in northern Cameroon.

\section{MATERIAL AND METHODS}

\section{Plant material}

The following species and seed origins were used:

- Quercus petraea (Matt) Liebl (Fagaceae; subgenus Lepidobalanus, section robur) either 40year-old trees growing in a natural stand at Nancy-Champenoux; or seed collected in the Forêt de la Reine, near Toul, eastern France (5.50 E, $48.40 \mathrm{~N}$; elevation $250 \mathrm{~m}$ );
- $Q$ robur L (Lepidobalanus, robur), from Manoncourt, near Toul, eastern France $(5.50 \mathrm{E}$, $48.40 \mathrm{~N}$; elevation $250 \mathrm{~m}$ );

- $Q$ pubescens Willd (Lepidobalanus, robur), from Mont Ventoux, Avignon, Vaucluse (5.12 E, $44.15 \mathrm{~N}$; elevation $800 \mathrm{~m}$ );

- $Q$ rubra L (Erythrobalanus, rubraea), from Schopperten Forest, the Bas Rhin, eastern France $(6.25 \mathrm{E}, 48.50 \mathrm{~N}$; elevation $250 \mathrm{~m})$;

- $Q$ ilex $L$ (Lepidobalanus, ilex), from Uzès, Gard, southern France (4.25 E, $44.05 \mathrm{~N}$; elevation $350 \mathrm{~m}$ );

- $Q$ cerris (Lepidobalanus, cerris), provided by Vilmorin, France.

Acorns from all these species were collected during autumn 1989 , stored over winter at $-1{ }^{\circ} \mathrm{C}$, and germinated during March 1990. $Q$ petraea and $Q$ robur are mid-European species which grow under rather well-watered conditions, while $Q$ pubescens and $Q$ cerris are located in drier areas. $Q$ ilex is a typical sempervirent macchia species with sclerophyllous leaves. $Q$ rubra was introduced from northeastern America;

- Populus candicans Ait (Salicaceae, section balsamifera), provided by the Laboratory of Forest Pathology, INRA-Nancy, originating from Northern America and drought-intolerant;

- Azadirachta indica A Juss (Meliaceae) from Maroua, Northern Cameroon (14.15 E, $10.40 \mathrm{~N}$, elevation $400 \mathrm{~m}, 780 \mathrm{~mm}$ rainfall). This species originates from Southern India and is now widely used in a Sahelian environment;

- Dalbergia sissoo (Papilionaceae), from Ouadagoudou, Burkina Faso (1.31 W, $12.21 \mathrm{~N}$, elevation $304 \mathrm{~m}, 860 \mathrm{~mm}$ rainfall). This species originates from Southern India, and is now being tested in a Sahelian environment;

- Acacia holosericea (Papilionaceae), from Mount Molloy, Australia (145.15 E, 16.46 S, elevation $380 \mathrm{~m}, 1150 \mathrm{~mm}$ rainfall) is a phyllodebearing Acacia shrub originating from Australia, tested in a Sahelian environment;

- Eucalyptus camaldulensis Dehn (Myrtaceae), from Djarengol, Cameroon (14.15 E, $10.40 \mathrm{~N}$, elevation $400 \mathrm{~m}, 780 \mathrm{~mm}$ rainfall) is widely used in a Sudano-Sahelian environment, but seems poorly adapted to drier climates (Sall et al, 1991).

The last 4 species were sown during the spring 1989. All seedlings were grown in 5-l pots on a mixture of blond peat and sand $(50 / 50 \mathrm{v} / \mathrm{v})$ 
and fertilized with a slow release fertilizer (Nutricote, N/P/K 13/13/13) and a solution of oligoelements. All seedlings were grown in a greenhouse where irradiance was reduced by $\approx 30 \%$. Temperatures ranged between $10-30{ }^{\circ} \mathrm{C}$ for temperate and between $15-30{ }^{\circ} \mathrm{C}$ for tropical species. Seedlings were watered manually twice a week.

The following rating for drought tolerance is suggested, based on species distribution: $P$ candicans $<Q$ rubra, $Q$ robur, $Q$ petraea $<$ $Q$ cerris, $E$ camaldulensis < $Q$ pubescens, $D$ sissoo $<A$ indica, $Q$ ilex $<A$ holesericea.

\section{Dehydration experiments}

Forty to 60 leaf disks (2.0 in diameter) were punched from 2-3 well-grown seedlings, which had previously been fully hydrated and darkadapted over a 14-h period. Disks were immediately weighed $\left(F W_{i}\right)$, and dehydrated for $0-8 \mathrm{~h}$ in the dark at room temperature as described by Epron and Dreyer (1992). Fluorescence induction kinetics were recorded successively on each disk and corresponding values of fresh weight $(F W)$ were determined immediately after completion of the kinetics. Dry weight (DW) was measured after $24 \mathrm{~h}$ oven-drying at $80^{\circ} \mathrm{C}$. Relative leaf water loss $(D)$ was always estimated as:

$$
D=1-\left[\left(F W-D W /\left(F W_{i}-D W\right)\right] .\right.
$$

\section{Fluorescence measurements}

Fluorescence measurements were carried out at ambient $\mathrm{CO}_{2}$ and temperature on darkadapted leaf disks with a PAM 101 fluorometer (Walz, Germany). Initial fluorescence $\left(F_{0}\right)$ was determined by applying a pulsed measuring red light $\left(<1 \mu \mathrm{mol} \mathrm{m} \mathrm{m}^{-2} \mathrm{~s}^{-1}\right)$ at a frequency of 1.6 $\mathrm{kHz}$, and maximal fluorescence $\left(F_{\mathrm{m}}\right)$ by an additional saturating flash of white light $(0.7 \mathrm{~s} ; 4000$ $\mu \mathrm{mol} \mathrm{m}^{-2} \mathrm{~s}^{-1}$ ) provided by a cold light source (Schott KL1500, Germany). The ratio of variable to maximal fluorescence $F_{v} / F_{m}$, that is the maximal PS II photochemical efficiency was calculated as (Genty et al, 1987):

$$
F_{v} / F_{\mathrm{m}}=1-F_{0} / F_{\mathrm{m}}
$$

After complete relaxation from this flash, a fluorescence kinetic was induced by an actinic white light (Schott KL1500, Germany; $220 \mu \mathrm{mol}$ $\mathrm{m}^{-2} \mathrm{~s}^{-1}$ ). After $10 \mathrm{~min}$ steady-state fluorescence (F) was recorded and a new flash yielded $F_{\mathrm{m}^{\prime}}$, allowing the calculation of an actual PS II photochemical efficiency $\left(\Delta F / F_{\mathrm{m}^{\prime}}\right)$ at $220 \mu \mathrm{mol} \mathrm{m} \mathrm{m}^{-2} \mathrm{~s}^{-1}$ from (Genty et al, 1989):

$$
\Delta F / F_{\mathrm{m}^{\prime}}=1-F / F_{\mathrm{m}^{\prime}}
$$

The actinic light was immediately switched off, and $F_{0}$ recorded, allowing calculation of the photochemical efficiency of open PS II reaction centers $\left(F_{\mathrm{v}^{\prime}} / F_{\mathrm{m}^{\prime}}=1-F_{0^{\prime}} / F_{\mathrm{m}^{\prime}}\right)$. Both parameters are related by:

$$
\Delta F / F_{\mathrm{m}^{\prime}}=q \mathrm{p}^{*} F_{\mathrm{v}^{\prime}} / F_{\mathrm{m}^{\prime}}
$$

where $q p$ is the photochemical quenching coefficient, ie the fraction of open PS II reaction centers (Genty et al, 1989; Baker, 1991). Decreases in $F_{\mathrm{v}} / F_{\mathrm{m}}$ are an index for increased PS II thermal deexcitation.

\section{Leaf characteristics}

Leaf specific weight ( $L S W, \mathrm{~g} \mathrm{dm}^{-2}$ ) was computed from disk dry weight and estimated disk area $\left(0.03141 \mathrm{dm}^{2}\right)$, and averaged for all used disks. Chlorophyll was extracted from 5 leaf disks per species (15 $\mathrm{mm}$ in diameter) in $5 \mathrm{ml}$ dimethylsulfoxide and chlorophyll concentrations were determined spectrometrically (Hiscox and Israelstam, 1979).

\section{Shoot-water relations}

Three shoots were selected for each species and pressure-volume curves established using the free transpiration method as described by Hinckley et al (1980) and Dreyer et al (1990). Each shoot was rehydrated overnight through the cut end, and left to transpire freely on a laboratory bench. Fresh weight and leaf water potential were recorded together at regular intervals till the latter reached $-6 \mathrm{MPa}$. Water potential was measured with a pressure chamber, and the main parameters of water relations (osmotic pressure at full turgor, $\pi_{0}$, water potential 
at turgor loss, $\psi_{\mathrm{wtl}}$, relative leaf water loss at turgor loss, $D_{t 1}$ ) calculated as in Dreyer et al (1990).

\section{Analysis of results}

For each species, values of $F_{0}, F_{m}, F_{v} / F_{m}, \Delta F / F_{m^{\prime}}$ were plotted against relative leaf water loss $D$. Optimal values of these parameters were recorded. Successive linear regressions were used to determine the range of stability of $F_{0}$. $F_{\mathrm{m}}, F_{\checkmark} J F_{\mathrm{m}}, \Delta F / F_{\mathrm{m}^{\prime}}$ with increasing $D$, and the threshold values for which statistically significant declines could be observed were computed.

\section{RESULTS}

\section{Leaf characteristics and water relations}

Leaf characteristics are listed in table I. $L S W$ was very variable among the species studied, and relatively low, due probably to growth under greenhouse conditions. $Q$ petraea had much higher LSW when grown under field conditions. Two species differed significantly from the others: $A$ holsericea has very thick hairy phyllodes, and $Q$ ilex has sclerophyllous waxy leaves. $P$ candicans displayed by far the lowest LSW. Total chlorophyll content expressed on a leaf area basis varied strongly between 2.36 and $7.35 \mathrm{mg} \mathrm{dm}^{-2}$. Oaks displayed the highest chlorophyll content, with $Q$ rubra slightly lower than the others. In general, tropical species exhibited the lowest values (<3 mg.dm ${ }^{-2}$ ). No clear correlation was found between LSW and chlorophyll content.

Parameters of shoot-water relations (osmotic potential at full turgor, $\pi_{0}$; relative leaf water loss at turgor loss $D_{t \mid}$; leaf water potential at turgor loss $\Psi_{\mathrm{wt}}$; and leaf water potential at $D=0.3$ ) are presented in table II. All species displayed rather high values of $\pi_{0}$, that is low solute contents. The lowest values were obtained with the Mediterranean oaks $Q$ ilex and $Q$ cerris. Tropical species showed even higher values than

Table I. Leaf characteristics of the tested species.

\begin{tabular}{lcccc}
\hline Species & $\begin{array}{c}\text { LSW } \\
\left(g d m^{-2}\right)\end{array}$ & $\begin{array}{c}C h / \text { a } \\
\left(m g d m^{-2}\right)\end{array}$ & $\begin{array}{c}\text { Ch/ tot } \\
\left(m g d m^{-2}\right)\end{array}$ & $C h / a / b$ \\
\hline Populus candicans & 0.27 & - & - & - \\
Quercus robur & 0.64 & 4.36 & 5.74 & 3.16 \\
Quercus rubra & 0.60 & 3.22 & 3.95 & 2.49 \\
Quercus petraea & 0.63 & 4.22 & 5.93 & 2.66 \\
Quercus petraea (stand) & 1.01 & 5.30 & 7.35 & 2.64 \\
Quercus cerris & 0.76 & 4.82 & 6.66 & 3.02 \\
Quercus pubescens & 0.72 & 4.61 & 6.16 & 2.79 \\
Quercus ilex & 1.30 & 4.96 & 5.20 & 3.68 \\
Eucalyptus camaldulensis & 0.87 & 1.86 & 2.36 & 4.52 \\
Dalbergia sissoo & 0.51 & 2.38 & 2.90 & 5.18 \\
Azadirachta indica & 0.63 & 2.05 & 2.45 & - \\
Acacia holosericea & 1.50 & - & - & \\
\hline
\end{tabular}

LSW: leaf specific weight; $\mathrm{Chl}$ a and $\mathrm{Chl}$ tot: concentrations in chlorophyll $\mathrm{a}$, and $\mathrm{a}+\mathrm{b}$ respectively expressed on a leaf area basis; $\mathrm{Chl} a / \mathrm{b}$ : ratio of chlorophyll $a$ to chlorophyll $b$. Species sequence reflects supposed increasing drought tolerance. 
Table II. Water relations of shoots from the tested species, as derived from pressure-volume curves.

\begin{tabular}{|c|c|c|c|c|}
\hline Species & $\begin{array}{c}\pi_{0} \\
(\mathrm{MPa})\end{array}$ & $\mathrm{D}_{t l}$ & $\begin{array}{c}\Psi_{w t l} \\
(M P a)\end{array}$ & $\Psi_{w(0.3)}$ \\
\hline Populus candicans $(n=1)$ & -1.56 & 0.115 & -2.05 & -3.80 \\
\hline Quercus robur & $-1.49 \pm 0.11$ & $0.146 \pm 0.032$ & $-1.76 \pm 0.13$ & -2.10 \\
\hline Quercus rubra & $-1.71 \pm 0.04$ & $0.123 \pm 0.0126$ & $-2.07 \pm 0.07$ & -3.30 \\
\hline Quercus petraea & $-1.61 \pm 0.10$ & $0.141 \pm 0.0140$ & $-1.85 \pm 0.06$ & -2.40 \\
\hline Quercus petraea (stand) & -2.26 & 0.208 & -3.04 & - \\
\hline Quercus cerris & $-2.14 \pm 0.15$ & $0.133 \pm 0.362$ & $-2.51 \pm 0.24$ & -3.20 \\
\hline Quercus pubescens & $-1.67 \pm 0.05$ & $0.110 \pm 0.0209$ & $-2.01 \pm 0.17$ & -2.70 \\
\hline Quercus ilex & $-2.12 \pm 0.06$ & $0.123 \pm 0.0119$ & $-2.45 \pm 0.01$ & -3.30 \\
\hline Eucalyptus camaldulensis & $-1.68 \pm 0.28$ & $0.147 \pm 0.0371$ & $-2.11 \pm 0.42$ & -2.80 \\
\hline Dalbergia sissoo & $-1.50 \pm 0.14$ & $0.123 \pm 0.0310$ & $-1.74 \pm 0.06$ & -2.20 \\
\hline Azadirachta indica & $-1.28 \pm 0.02$ & $0.098 \pm 0.0160$ & $-1.57 \pm 0.08$ & -2.70 \\
\hline Acacia holosericea & $-1.41 \pm 0.03$ & $0.101 \pm 0.0171$ & $-1.60 \pm 0.07$ & -2.00 \\
\hline
\end{tabular}

$\pi_{0}$ : osmotic potential at full turgor; $D_{\mathrm{fl}}$; relative leaf water loss at turgor loss point; $\psi_{\mathrm{wtl}}$ : leaf water potential at turgor loss; $\psi_{\text {w(0.3) }}$ : leaf water potential at $D=0.3$. Means $\pm S D$.

the oaks. Turgor loss occurred at very low relative leaf water loss $\left(D_{t 1}\right)$ between 0.1 and 0.15 , and at relatively high leat water potentials $\left(\psi_{\mathrm{wt}} \geq-2.5 \mathrm{MPa}\right)$. It is interesting to note that the lowest $\pi_{0}$ and $\psi_{w t \mid}$ and highest $D_{\mathrm{tl}}$ occurred in $Q$ petraea in the stand. Finally, $\psi_{\mathrm{w}}$ at a deficit of 0.3 varied between -2.0 and $-3.8 \mathrm{MPa}$ which was largely below the turgor loss point for all species. Greenhouse microclimate probably had a major effect on leaf water relations, and $\pi_{0}$ and $D_{\mathrm{tl}}$ would probably have been higher under field conditions (Dreyer et al, 1990). Despite a strong interspecific variability, no clear trend could be detected in these results in relation to the ecological adaptation of species to drought.

\section{Fluorescence measurements}

Three representative examples of evolution of $F_{0}, F_{\mathrm{m}}, F_{\mathrm{v}} / F_{\mathrm{m}}$, and $\Delta F / F_{\mathrm{m}^{\prime}}$ with increasing dehydration have been indicated in figure 1 ( $P$ candicans, $E$ camaldulensis and $Q$ ilex). The main features of these relations were as follows. In $P$ candicans, $F_{0}$ was almost constant over the entire range of $D$ from 0 to 0.8 , while $F_{\mathrm{m}}$ remained constant till $D=0.4$, and decreased very gradually later. A very sharp decline occurred only after $D \approx 0.75$. As a consequence, $F_{\mathrm{v}} / F_{\mathrm{m}}$ remained rather constant at optimal values of $\approx 0.82$. A sharp decline occurred also only above $D \approx 0.75$. $\Delta F / F_{\mathrm{m}^{\prime}}$ was almost constant at the high values of 0.62 till $D \approx 0.4$ and declined sharply thereafter. Ecamaldulensis presented almost the same behaviour with a slight difference: $F_{m}$ decreased progressively during the whole range of $D$, together with $F_{0}$, and $F_{V} / F_{\mathrm{m}}$ showed a slow decrease from $D \approx 0.4$ on. Nevertheless, final values at $D \approx 0.8$ were still around 0.75 . The same description also applied to $Q$ ilex, with the strong difference that $\Delta F / F_{\mathrm{m}^{\prime}}$ decreased much earlier, ie at $D \approx 0.2$.

Such a feature fits very well with that already described by Epron and Dreyer (1992): maintenance of high values of 


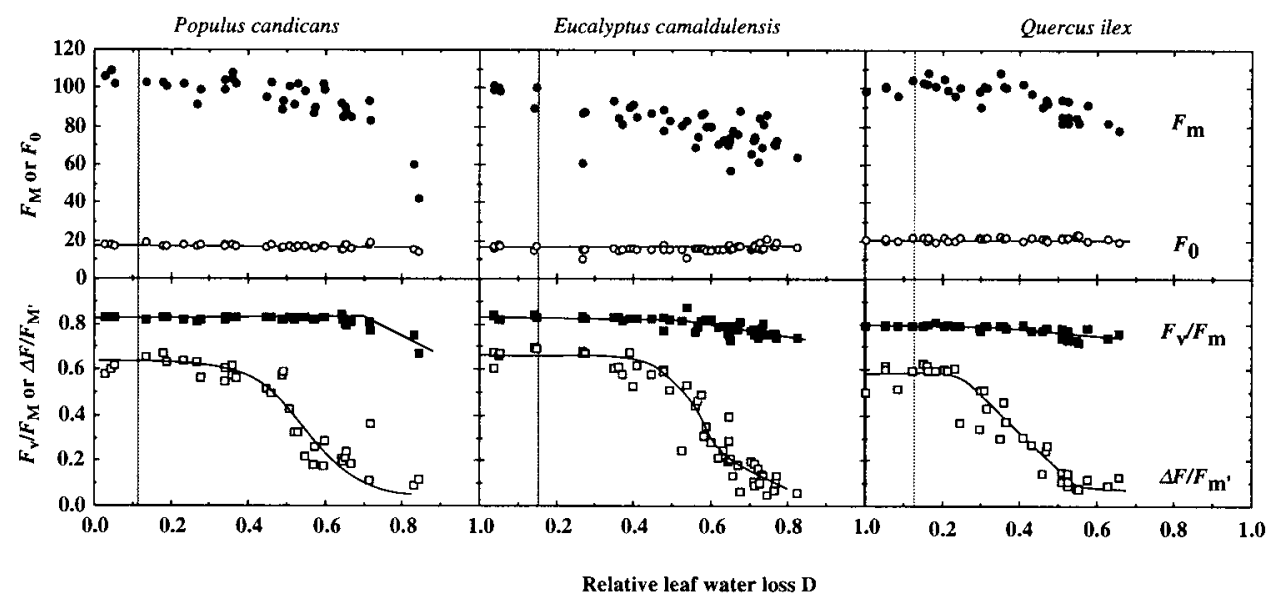

Fig 1. Effects of increasing relative leaf water loss $(D)$ under darkness on initial and maximal fluorescence $F_{0}$ and $F_{m}$, on PS II photochemical efficiency of dark-adapted leaves $F_{\mathrm{v}} / F_{\mathrm{m}}$, and on PS II photochemical efficiency after $10 \mathrm{~min}$ at $220 \mu \mathrm{mol} \mathrm{m}{ }^{-2} \cdot \mathrm{s}^{-1}\left(\Delta F / F_{\mathrm{m}^{\prime}}\right)$. Results from the following 3 species are shown: Populus candicans, Eucalyptus camaldulensis and Quercus ilex. Each point is the result from an individual leaf disk. Dotted lines indicate the value of $D$ at turgor loss for each species.

PS II maximal photochemical efficiency $\left(F_{\mathrm{v}} / F_{\mathrm{m}}\right)$ up to very strong levels of dehydration, and decline in photosynthetic activity, as estimated by PS II photochemical efficiency under low irradiance $\left(\Delta F / F_{\mathrm{m}^{\prime}}\right)$, only beyond the turgor loss point.

The decrease in $\Delta F / F_{m}$ was also accompanied by a decrease in $q p$, although some species-related differences appeared in the relationship between both parameters (fig 2 ). In fact, in both $P$ candicans and $E$ camaldulensis, an almost straight relationship appeared, while in $Q$ ilex the first stages of decrease were accompanied by a maintenance of high $q p$, ie a high oxidation state of the primary electron acceptor QA. In the meantime, the photochemical efficiency of open centers $F_{\mathrm{v}^{\prime}} / F_{\mathrm{m}^{\prime}}$ decreased till a minimal value was reached, and reincreased. The magnitude of the changes in $F_{\mathrm{v}} / F_{\mathrm{m}}$ were very different between species, the largest being recorded in $Q$ ilex.
To enable a comparative analysis to be made of the response curves to dehydration in all species we computed the following parameters (table III): $F_{\mathrm{m}}, F_{\mathrm{v}} / F_{\mathrm{m}}, \Delta F / F_{\mathrm{m}^{\prime}}$ at optimal water content $(D<0.2)$, the threshold in $D$ below which $\Delta F / F_{\mathrm{m}^{\prime}}$ declined strongly, the minimal value of $F_{\mathrm{v}^{\prime}} / F_{\mathrm{m}^{\prime}}$ and $\Delta$, the magnitude of changes in $F_{\mathrm{v}^{\prime}} / F_{\mathrm{m}^{\prime}}$ during dehydration.

Optimal values of $F_{\mathrm{m}}$ ranged from 73.4 to 112.9 respectively depending on species. These species-related differences could be partly attributed to variations in leaf total chlorophyll content. This was the only fluorescence parameter which could be correlated to a leaf structural feature. Maximal values of $F_{v} / F_{\mathrm{m}}$ averaged 0.800 , with some significant differences between species (range: 0.774 for $A$ indica, and 0.826 for $P$ candicans. During dehydration, $F_{\mathrm{v}} / F_{\mathrm{m}}$ remained almost constant, with only slight decreases in a few species. In any case, even at $D \approx 0.7, F_{\mathrm{v}} / F_{\mathrm{m}}$ was still 


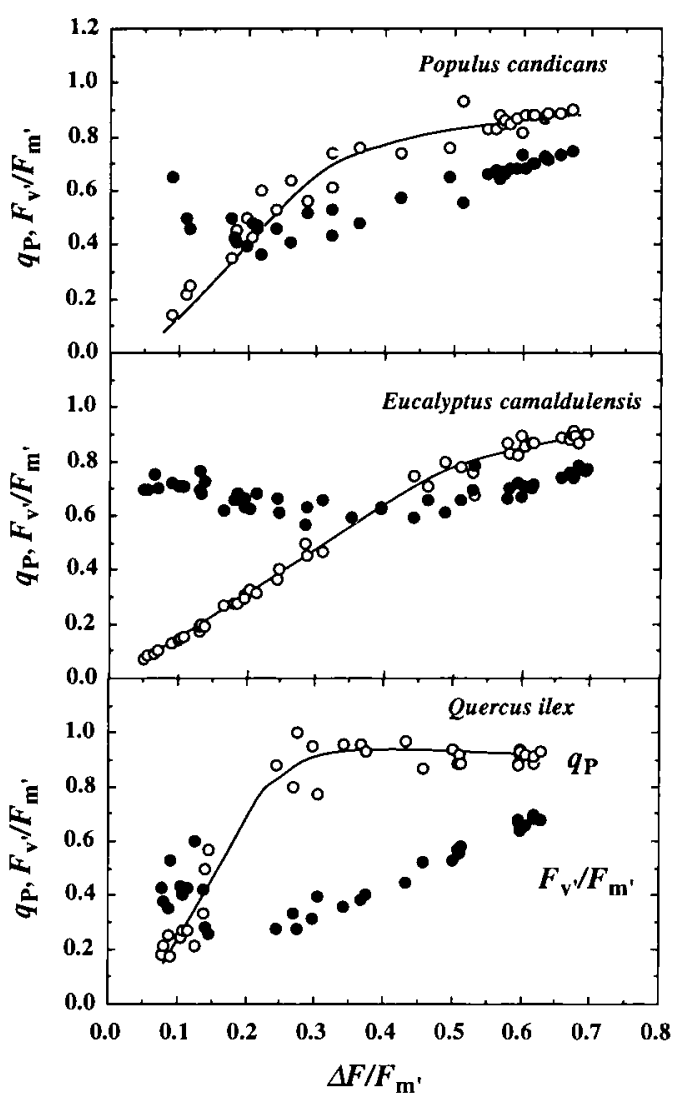

Fig 2. Relationship between PS II photochemical efficiency $\left(\Delta F / F_{m^{\prime}}\right)$, photochemical quenching $(q p)$ and photochemical efficiency of open PS II centers $\left(F_{v^{\prime}} / F_{m^{\prime}}\right)$ as modified by increasing dehydration in Populus candicans, Eucalyptus camaldulensis and Quercus ilex. Measurements obtained after a 10-min induction period at $220 \mu \mathrm{mol} \mathrm{m} \mathrm{m}^{-2} \cdot \mathrm{s}^{-1}$. Each point is the result from an individual leaf disk. Open disks: $q p$; black disks: $F_{\mathrm{v}} / F_{\mathrm{m}}$ :

around 0.75 . Sharp declines were observed only when $D>0.7 . \Delta F / F_{\mathrm{m}^{\prime}}$ displayed high values between 0.60 and 0.66 depending on the species, and remained almost constant until a threshold in $D$ was reached ranging from 0.23 in $Q$ cerris to
0.40 in $Q$ robur. This threshold value was in all cases above the turgor loss point, and was apparently not related to the known ability of species to withstand drought stress. Finally, the dehydration induced changes in $F_{\mathrm{v}^{\prime}} / F_{\mathrm{m}^{\prime}}$ displayed a strong interspecific variability; both minimal values $(0.25$ for $Q$ ilex to 0.57 for $E$ camaldulensis) and the magnitude of decline ( 0.44 for $Q$ ilex to 0.17 for $Q$ robur) were very variable.

\section{DISCUSSION}

The results presented here confirm the observations made by a number of authors, showing that the photosynthetic functions are very unresponsive to leaf dehydration (Kaiser, 1987; Cornic et al, 1989; Cornic and Briantais, 1991; Epron and Dreyer, 1992). In fact, for all species the PS II photochemical efficiency of dark-adapted leaves $\left(F_{\checkmark} / F_{\mathrm{m}}\right)$ declined strongly only at relative leaf water losses $>0.7$. The PS II photochemical efficiency at $220 \mu \mathrm{mol} \mathrm{m} \mathrm{m}^{-2} \mathrm{~s}^{-1}$ $\left(\Delta F / F_{\mathrm{m}^{\prime}}\right)$ decreased sharply below 0.25 , that is after turgor loss, and probably at relative leaf water losses where net $\mathrm{CO}_{2}$ assimilation rates should be almost nil for all the species used here (Epron and Dreyer, 1990). Under such conditions, it is indicated from the results of Cornic and Briantais (1991) that photorespiration may consume the electron flow produced by PS II activity; as a matter of fact, all species tested display a $\mathrm{C}_{3}$ metabolism.

The increase in relative leaf water loss beyond this level induced a strong decline in photochemical efficiency at low irradiance $\left(\Delta F / F_{\mathrm{m}^{\prime}}\right)$. The absence of decrease in PS II maximal photochemical efficiency $\left(F_{v} / F_{\mathrm{m}}\right)$ and of increases in $F_{0}$ clearly demonstrated that the declines could not be attributed to decreased potential activity of PS II reaction centers. But in all cases they 
Table III. Some remarkable values of PS II photochemical efficiency as measured in response to increasing leaf water loss.

\begin{tabular}{|c|c|c|c|c|c|c|}
\hline Species & $\mathrm{F}_{\text {mopt }}$ & $F / F_{\text {mopt }}$ & $\Delta \mathrm{F} / F_{\text {m'opt }}$ & $\mathrm{D}_{t h}$ & $\mathbf{F}_{v} F_{\text {m'min }}$ & $\Delta$ \\
\hline Populus candicans & $100.8 \pm 2.78$ & $0.826 \pm 0.003$ & 0.635 & 0.34 & 0.37 & 0.37 \\
\hline Quercus robur & $103.9 \pm 1.99$ & $0.815 \pm 0.004$ & 0.66 & 0.40 & 0.56 & 0.17 \\
\hline Quercus rubra & $98.6 \pm 2.31$ & $0.779 \pm 0.006$ & 0.66 & 0.29 & 0.37 & 0.32 \\
\hline Quercus petraea & $112.9 \pm 2.26$ & $0.803 \pm 0.003$ & 0.65 & 0.34 & 0.42 & 0.28 \\
\hline Quercus petraea (stand) & $103.6 \pm 2.52$ & $0.808 \pm 0.005$ & 0.66 & 0.38 & 0.42 & 0.30 \\
\hline Quercus cerris & $92.8 \pm 1.71$ & $0.798 \pm 0.050$ & 0.64 & 0.23 & 0.50 & 0.23 \\
\hline Quercus pubescens & $100.0 \pm 1.80$ & $0.808 \pm 0.010$ & 0.66 & 0.28 & 0.40 & 0.33 \\
\hline Quercus ilex & $100.5 \pm 1.77$ & $0.790 \pm 0.004$ & 0.60 & 0.25 & 0.25 & 0.44 \\
\hline Eucalyptus camaldulensis & $86.3 \pm 3.88$ & $0.820 \pm 0.008$ & 0.65 & 0.39 & 0.57 & 0.21 \\
\hline Dalbergia sissoo & $81.9 \pm 2.80$ & $0.796 \pm 0.008$ & 0.62 & 0.39 & 0.48 & 0.25 \\
\hline Azadirachta indica & $79.3 \pm 0.87$ & $0.774 \pm 0.006$ & 0.32 & - & 0.44 & 0.23 \\
\hline Acacia holosericea & $73.4 \pm 1.90$ & $0.827 \pm 0.008$ & 0.60 & 0.34 & 0.54 & 0.20 \\
\hline
\end{tabular}

$F_{\text {mopt }}$ : maximal fluoresence of dark-adapted leaf disks at optimal water content; $F_{\checkmark} / F_{\text {mopt }}:$ PS II photochemical efficiency of dark-adapted disks at optimal water content; $\Delta F / F_{\text {m'opt }}$ : PS II photochemical efficiency after a 10-min induction period at $220 \mu \mathrm{mol} \mathrm{m} \mathrm{m}^{-2} \mathrm{~s}^{-1}$ at optimal water content; $D_{\text {th }}$ : threshold of relative leaf water loss at which a decline

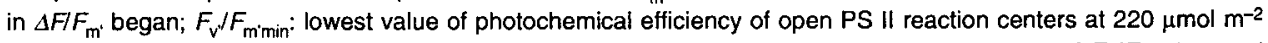
$\mathrm{s}^{-1}$ measured during the course of dehydration; $\Delta$ : difference between highest and lowest values of $F_{\mathrm{v}} / F_{\mathrm{m}}$ observed during dehydration; this parameter may be considered as an index for the intensity of dehydration induced changes in PS II thermal deexcitation.

were accompanied by a decrease in the photochemical efficiency of open PS II reaction centers $\left(F_{\mathrm{v}^{\prime}} / F_{\mathrm{m}^{\prime}}\right)$, which reflected increased PS II thermal deexcitation (Genty et al, 1989). This in some cases allowed maintenance of high states of oxidation of the primary acceptor $Q_{A}$, as revealed by high values of the photochemical quenching $q p$, or at least slowed down the reduction of this acceptor pool. Epron and Dreyer (1992) showed that at this stage, an efficient recovery of $F_{\mathrm{v}^{\prime}} / F_{\mathrm{m}^{\prime}}$ occurred in a few minutes as soon as the actinic light had been switched off, which indicates that the decreases were due to a fast relaxing non-photochemical quenching. Highest levels of $D$ finally resulted in a reincrease of $F_{\mathrm{v}^{\prime}} / F_{\mathrm{m}^{\prime}}$ and in a strong decline of $q p$.

Despite large differences in leaf structures among species, only minor variations were detected in PS II photochemical efficiency, both after dark adaptation (which remained $\approx 0.82$ ) and after $10 \mathrm{~min}$ at 220 $\mu \mathrm{mol} \mathrm{m} \mathrm{m}^{-2} \mathrm{~s}^{-1}(\approx 0.62)$. The only significant change was detected in $F_{\mathrm{m}}$, which in fact was related to the amount of chlorophyll per leaf area. This is not surprising since, as has been demonstrated by Björkman and Demmig (1987), maximal quantum yield of photosynthesis is identical in all $C_{3}$ species and corresponds to an efficiency of $\approx 0.83$ electrons issued from PS II per intercepted photon.

The reactions to dehydration were similar in all species. No significant interspecific differences could be detected in the sensitivity of PS II maximal photochemical efficiency $\left(F_{\mathrm{v}} / F_{\mathrm{m}}\right)$. Some important differences appeared in the precocity of the decline of photochemical efficiency at 220 
$\mu \mathrm{mol} \mathrm{m}^{-2} \mathrm{~s}^{-1}$, revealing changes in photosynthetic activity. But surprisingly, the species which was supposed to display the best adaptation to drought also showed the earliest decrease (over $D=0.34$ for $P$ candicans, and $D=0.25$ for $Q$ ilex)!

The largest interspecific difference appeared in the magnitude of changes in $F_{v^{\prime}}$ $F_{m^{\prime}}$, in relation to decreased $\Delta F / F_{\mathrm{m}^{\prime}}$. They reflect differences in the magnitude of $P S$ II thermal deexcitation while the photochemical efficiency decreases. The largest levels were displayed by $Q$ ilex, and helped to maintain high values of $q p$, that is a high oxidation state of the primary acceptor QA. This feature could be considered as an index for a better tolerance to relative leaf water losses, but it should be kept in mind that the photochemical efficiency also decreased rather early in this species and that $P$ candicans, one of the most drought-sensitive species tested here, also displayed rather high values.

In conclusion, these results emphasize the very poor correlation existing between drought resistance of different species and the sensitivity of their photosynthetic functions to leaf dehydration. This result is in accordance with much other experimental evidence. In fact, the decrease in photosynthetic activity in response to drought under natural conditions is probably not related to dysfunction induced by leaf dehydration, but to stomatal closure, as has been confirmed by direct measurement of $\mathrm{O}_{2}$ evolution under saturating $\mathrm{CO}_{2}$ (Cornic et al, 1989). Stomatal closure leads to low $\mathrm{CO}_{2}$ concentrations in the chloroplasts, and high irradiance and temperature increases associated with drought could induce deleterious effects (Chaves, 1991). The ability to withstand such periods of high irradiance and high temperature during drought may be the most significant physiological aspect of drought tolerance, together with the precocity of droughtinduced stomatal closure.

\section{ACKNOWLEDGMENTS}

The authors are most grateful to JM Gioria and JM Desjeunes for growing the seedlings used in this experiment. They also wish to thank the Centre Technique Forestier Tropical for providing the seeds from tropical species, and the French Ministère de la Coopération et du Développement for travel funds accorded to OEM. The comments of 2 anonymous reviewers on an earlier version of this paper are gratefully acknowledged.

\section{REFERENCES}

Baker NR (1991) A possible role for photosystem II in environmental perturbations of photosynthesis. Physiol Plant 81, 563-570

Björkman O, Demmig B (1987) Photon yield of $\mathrm{O}_{2}$ evolution and chlorophyll fluorescence characteristics at $77 \mathrm{~K}$ among vascular plants of diverse origins. Planta 170, 489-504

Chaves MM (1991) Effects of water deficits on carbon assimilation. J Exp Bot 42, 1-16

Cornic G, Papagiorgiou I, Louason G (1987) Effect of a rapid and a slow drought cycle followed by rehydration on stomatal and non stomatal components of leaf photosynthesis in Phaseolus vulgaris L. J Plant Physiol 126, 309-318

Comic G, Le Gouallec JL, Briantais JM, Hodges $M$ (1989) Effect of dehydration and high light on photosynthesis of two $C_{3}$ plants (Phaseolus vulgaris $L$, Elatostema repens (Lour) Hall $\mathrm{f}$ ). Planta 177, 84-90

Cornic G, Briantais JM (1991) Partitioning of photosynthetic electron flow between $\mathrm{CO}_{2}$ and $\mathrm{O}_{2}$ reduction in a $\mathrm{C} 3$ leaf (Phaseolus vulgaris $\mathrm{L}$ ) at different $\mathrm{CO}_{2}$ concentrations and during drought stress. Planta 183, 178-184

Dreyer E, Bousquet F, Ducrey M (1990) Use of pressure volume curves in water relation analysis on woody shoots: influence of rehydration and comparison of four European oak species. Ann Sci For 47, 285-297

Epron D, Dreyer E (1990) Stomatal and nonstomatal limitation of photosynthesis by leaf water deficits in three oak species: a comparison of gas exchange and chlorophyll a fluorescence data. Ann Sci For 47, 435-450 
Epron D, Dreyer E (1992) Effects of severe dehydration on leaf photosynthesis in Quercus petraea (Matt) Liebl: photosystem II efficiency, photochemical and non-photochemical fluorescence quenchings and electrolyte leakage. Tree Physiol 10, 273-284

Genty B, Briantais JM, Vieira da Silva JB (1987) Effects of drought on primary photosynthetic processes of cotton leaves. Plant Physiol 83, 360-364

Genty B, Briantais JM, Baker NR (1989) The relationship between the quantum yield of photosynthetic electron transport and quenching of chlorophyll fluorescence. Biochem Biophys Acta 990, 87-92

Hinckley TM, Duhme F, Hinckley AR, Richter H (1980) Water relations of drought hardy shrubs: osmotic potential and stomatal reactivity. Plant Cell Environ 3, 131-140

Hiscox JD, Israelstam GF (1979) A method for the extraction of chlorophyll from leaf tissue without maceration. Can J Bot 57, 1332-1334

Kaiser WM (1987) Effects of water deficit on photosynthetic capacity. Physiol Plant 71, 142-149

Ögren E, Öquist G (1985) Effects of drought on photosynthesis, chlorophyll fluorescence and photoinhibition susceptibility in intact willow leaves. Planta 166, 380-388

Sall PN, Aussenac G, Dreyer E, Granier A (1991) Limitation par la sécheresse de la croissance d'Eucalyptus camaldulensis Dehn en climat soudano-sahélien au Sénégal. Rev For Fr 43, 309-316 